\title{
Bioactive lipid profiling reveals drug target engagement of a soluble epoxide hydrolase inhibitor in a murine model of tobacco smoke exposure
}

\author{
Malin L. Nording ${ }^{1,2}$, Jun Yang ${ }^{2}$, Laura Hoang ${ }^{3}$, Vanessa Zamora ${ }^{3}$, Dale Uyeminami ${ }^{3}$, Imelda Espiritu ${ }^{3}$, Kent E. Pinkerton ${ }^{3}$, Bruce D. Hammock ${ }^{2}$ \\ and Ayala Luria ${ }^{2,4}$ \\ *Correspondence: bdhammock@ucdavis.edu

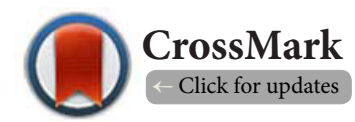 \\ 'Department of Chemistry, Umeå University, 90187 Umeå, Sweden. \\ 2Department of Entomology and Comprehensive Cancer Center, University of California-Davis, One Shields Ave, Davis, CA 95616, USA. \\ ${ }^{3}$ Center for Health and the Environment, University of California-Davis, Old Davis Rd, Davis, CA 95616, USA. \\ ${ }^{4}$ Medical Service, Veterans Affairs Palo Alto Healthcare System, PAVIR and Division of Immunology/Rheumatology, Stanford University \\ School of Medicine, Palo Alto, CA, USA.
}

\begin{abstract}
The inflammatory process underlying chronic obstructive pulmonary disease (COPD) may be caused by tobacco smoke (TS) exposure. Previous studies show that epoxyeicosatrienoic acids (EETs) possess promising anti-inflammatory properties, therefore stabilization of EETs and other fatty acid epoxides through inhibition of soluble epoxide hydrolase $(\mathrm{sEH})$ was investigated in mouse models of acute and subchronic inflammation caused by TS exposure. During the entire TS exposure, the potent sEH inhibitor 1-(1-methylsulfonyl-piperidin-4-yl)-3-(4-trifluoromethoxy-phenyl)-urea (TUPS) was given via drinking water. To assess drug target engagement of TUPS, a tandem mass spectrometry method was used for bioactive lipid profiling of a broad range of fatty acid metabolites, including EETs, and their corresponding diols (DHETs) derived from arachidonic acid, as well as epoxides and diols derived from other fatty acids. Several, but not all, plasma epoxide/diol ratios increased in mice treated with sEH inhibitor, compared to non-treated mice, suggesting a wider role for $\mathrm{sEH}$ involving more fatty acid precursors besides arachidonic acid. This study supports qualitative use of epoxide/diol ratios explored by bioactive lipid profiling to indicate drug target engagement in mouse models of TS exposure relevant to COPD, which may have ramifications for future therapeutic interventions of sEH.
\end{abstract}

Keywords: Arachidonic acid, epoxy eicosatrienoic acid, chronic obstructive pulmonary disease, soluble epoxide hydrolase, fatty acid metabolites, pulmonary inflammatory disease, tobacco smoke exposure

\section{Introduction}

Chronic obstructive pulmonary disease (COPD), an umbrella term for a group of lung disorders characterized by poorly reversible and progressive airway obstruction, is the third leading cause of death in the United States, and a majority (80-90\%) of COPDrelated deaths is those of smokers [1]. The heterogeneous and complex COPD pathology involves chronic inflammation of the respiratory tract, hypersecretion of mucus, small-airway remodeling, and emphysema [2]. Cigarette smoke-triggered inflammation is important in the pathophysiology of COPD, and involves overexpression of many proinflammatory genes [3]. Hence, transcription factors regulating expression of inflam- matory mediators may play a key role in characterizing the disease.

Anti-inflammatory COPD therapies have the potential to restrain disease progression, reduce symptoms and prevent exacerbations [4]. However, current treatment regimens using inhaled corticosteroids alone or in combination with $\beta_{2}$ agonists fail to reduce COPD inflammation $[5,6]$. Therefore, new and more effective COPD drugs are highly warranted. To that end, soluble epoxide hydrolase ( $\mathrm{sEH}$ ) is a potential novel COPD drug target, as previously shown in a rat COPD model $[7,8]$. The pharmacological inhibition of $s E H$ increases plasma levels of epoxyeicosatrienoic acids (EETs), the epoxygenation products of arachidonic acid (ARA) by cytochrome P450 monooxygenases 
Nording et al. Journal of Metabolomics 2015,

http://www.hoajonline.com/journals/pdf/2059-0008-1-1.pdf

doi: $10.7243 / 2059-0008-1-1$

(CYP) [9]. Since EETs possess anti-inflammatory properties [10], and is converted by sEH to diols, stabilization of the antiinflammatory EETs through sEH inhibitors ( $\mathrm{sEHI}$ ) is favorable [7,11-14].

EETs belong to the class of regulatory lipids termed eicosanoids. Eicosanoids are derived from ARA including important inflammatory mediators such as prostaglandins and leukotrienes produced via the cyclooxygenase- (COX), and lipooxygenase(LOX) pathways, respectively $[7,15]$. Similar compounds derived from other fatty acids such as linoleic acid (LA), a-linolenic acid (ALA), eicosapentaenoic acid (EPA), and docosahexaenoic acid (DHA), as well as ARA eicosanoids, are collectively known as oxylipins (Figure 1).

Previous data show that inhibition of $\mathrm{sEH}$ or deletion of its gene, and high levels of its substrates, EETs, are involved with endothelial signaling, angiogenesis and vascular endothelial growth factor (VEGF) secretion [17]. Maintenance of the microvasculature in the lung is critical for gas exchange, the integrity of the alveolar structure and tissue repair [18]. VEGF plays a vital role in development and maintenance of vasculature and tissue regeneration [19].

Lipid mediator profiling of the oxylipins using liquid chromatography coupled to tandem mass spectrometry (LC-MS/
MS) has proven useful in clinical and preclinical studies of airway diseases [20-23]. During tobacco smoke (TS) exposure in rats, changes in lung and BAL fluid oxylipin concentrations are accompanied with cellular infiltration to the lung [7]. We hypothesize that oxylipin profiles are shifted in mice lacking $s E H$ and in mice treated with selective inhibitors of $s E H$, with potential beneficial effects on cell infiltration after TS exposure. Since LC-MS/MS analysis is capable of capturing alterations in oxylipin profiles, we used this method to study drug target engagement by focusing on the oxylipin epoxide/diol ratios demonstrating the effectiveness of $s E H$ inhibition.

In order to test our hypothesis we investigated the effects of sEH inhibition on acute and sub-chronic TS-induced local and systemic oxylipin levels using pharmacological inhibition and Eph $\times 2$ gene-disruption. The acute model was chosen based on our previous study in hypertensive rats exposed to TS [7], and compared to a sub-chronic exposure model since mice are more resistant to tobacco smoke. For that purpose, wild-type (WT) mice treated with 1-(1-methylsulfonyl-piperidin-4-yl)-3(4-trifluoromethoxy-phenyl)-urea (TUPS), a potent inhibitor of $s E H$, and sEH knock-out (K/O) mice were exposed to TS for either two days or one month and compared to control animals exposed to filtered air.

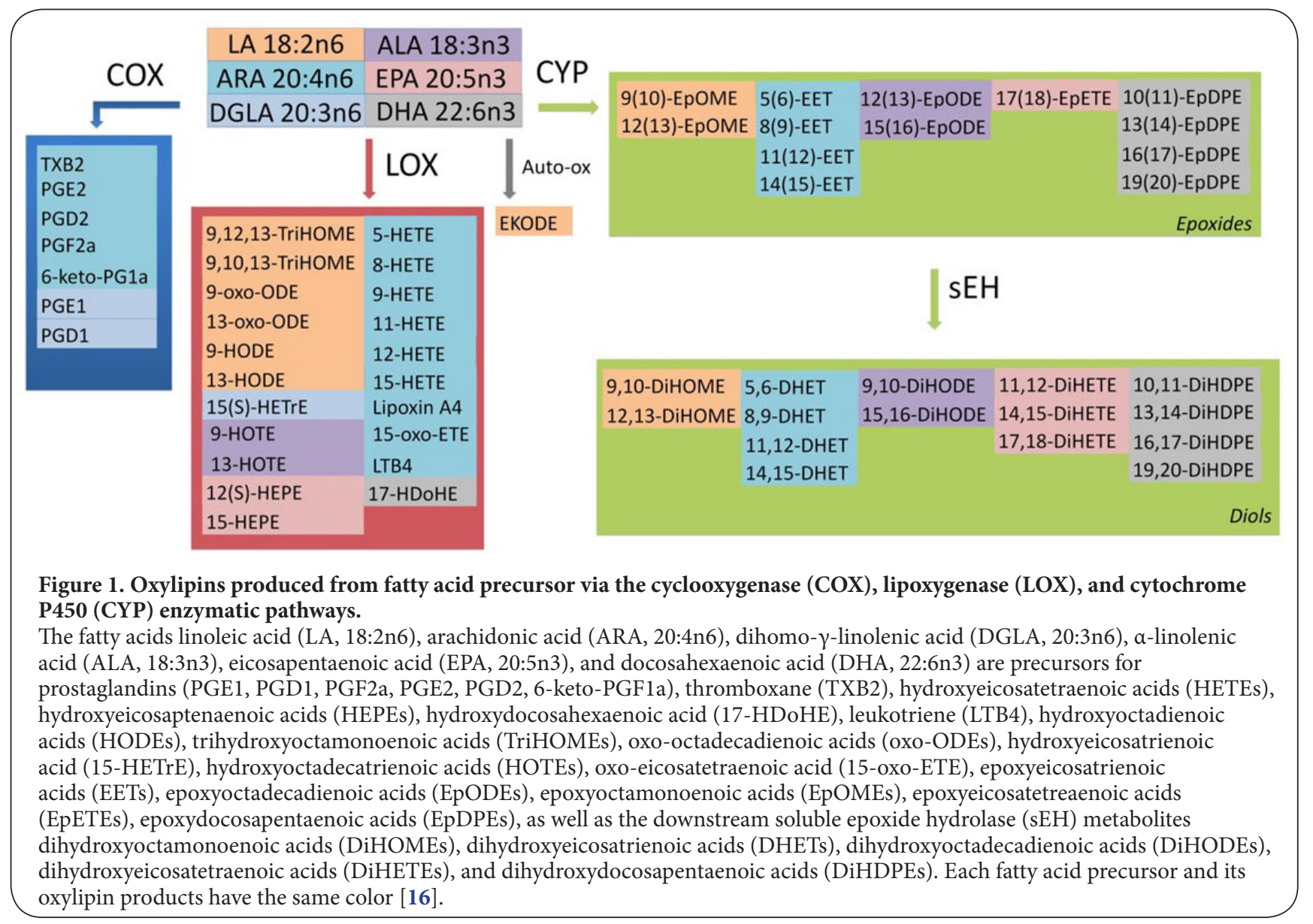


Nording et al. Journal of Metabolomics 2015,

\section{Materials and methods Animals}

Male WT C57BL/6 mice and their counterparts K/O mice with targeted disruption in exon 1 of the $\mathrm{sEH}$ gene back-crossed ten generation onto a $\mathrm{C} 57 \mathrm{BL} / 6$ genetic background at the breeding colony of University of California, Davis [24], were quarantined for one week before initialization of TS exposure. $\mathrm{K} / \mathrm{O}$ mice were maintained as heterozygotes and homologous $\mathrm{sEH} \mathrm{H}^{+}$and $\mathrm{sEH} \mathrm{H}^{-}$mice were selected from the crosses. Mice were housed in a standard animal facility under controlled temperature $\left(22^{\circ} \mathrm{C}\right)$ and photoperiod ( $12 \mathrm{~h}$ light, $12 \mathrm{~h}$ dark). They were maintained on a normal rodent diet (PicoLab rodent 20, LabDiet, Richmond, IN) ad libitum. WT mice were treated with sEHI TUPS via the drinking water $(10 \mathrm{mg} / \mathrm{l}$ in $10 \%$ polyethylene glycol 400) during the entire smoke exposure period. The synthesis and characterization of TUPS is described in Tsai et al [25]. Animal handling, experimentation, and sacrificing were conducted in accordance with standards established by the U.S. Animal Welfare Acts under the supervision of the University of California, Davis, Animal Care and Use Committee.

\section{Tobacco smoke exposure}

As described in Figure 2, WT $(n=6)$ and $\mathrm{K} / \mathrm{O}(\mathrm{n}=4)$ mice were exposed to filtered air or a mixture of side stream and mainstream TS in a smoking apparatus [26] at a mean concentration of $90-130 \mathrm{mg}$ total suspended particulates/ $\mathrm{m}^{3}$. Acute exposure (two days) was achieved with a total of 12 hours exposure during two days ( 90 followed by $120 \mathrm{mg} /$ $\mathrm{m}^{3}$ for 6 hours each day). This exposure condition represents an acute response to tobacco smoke in an active smoker. While, sub-chronic exposure (one month) was achieved with exposure for 6 hours/day, 5 days/week for one month (130 $\mathrm{mg} / \mathrm{m}^{3}$ ) (Figure 2). These exposure conditions represent a repeated and/or adapted response in a moderate smoker over a period of time (one month). Both conditions (acute and chronic exposure) in the mouse represent that of a moderate to possibly heavy smoker in humans. The cigarettes were humidified 2R4F research cigarettes (Tobacco Health Research Institute, Lexington, KY). An automatic metered puffer was used to smoke the cigarettes under Federal Trade Commission conditions (35-ml puff, 2 s duration, 1 puff per minute). The smoke was collected in a chimney, diluted with filtered air, and delivered to whole-body exposure chambers. Necropsies were performed 18 hours following the last day of TS exposure with an overdose of sodium pentobarbital.

\section{Blood collection}

Blood was sampled by cardiac puncture and collected into EDTA-rinsed syringes from the right ventricle of each animal. Plasma for TUPS analysis and oxylipin profiling was separated

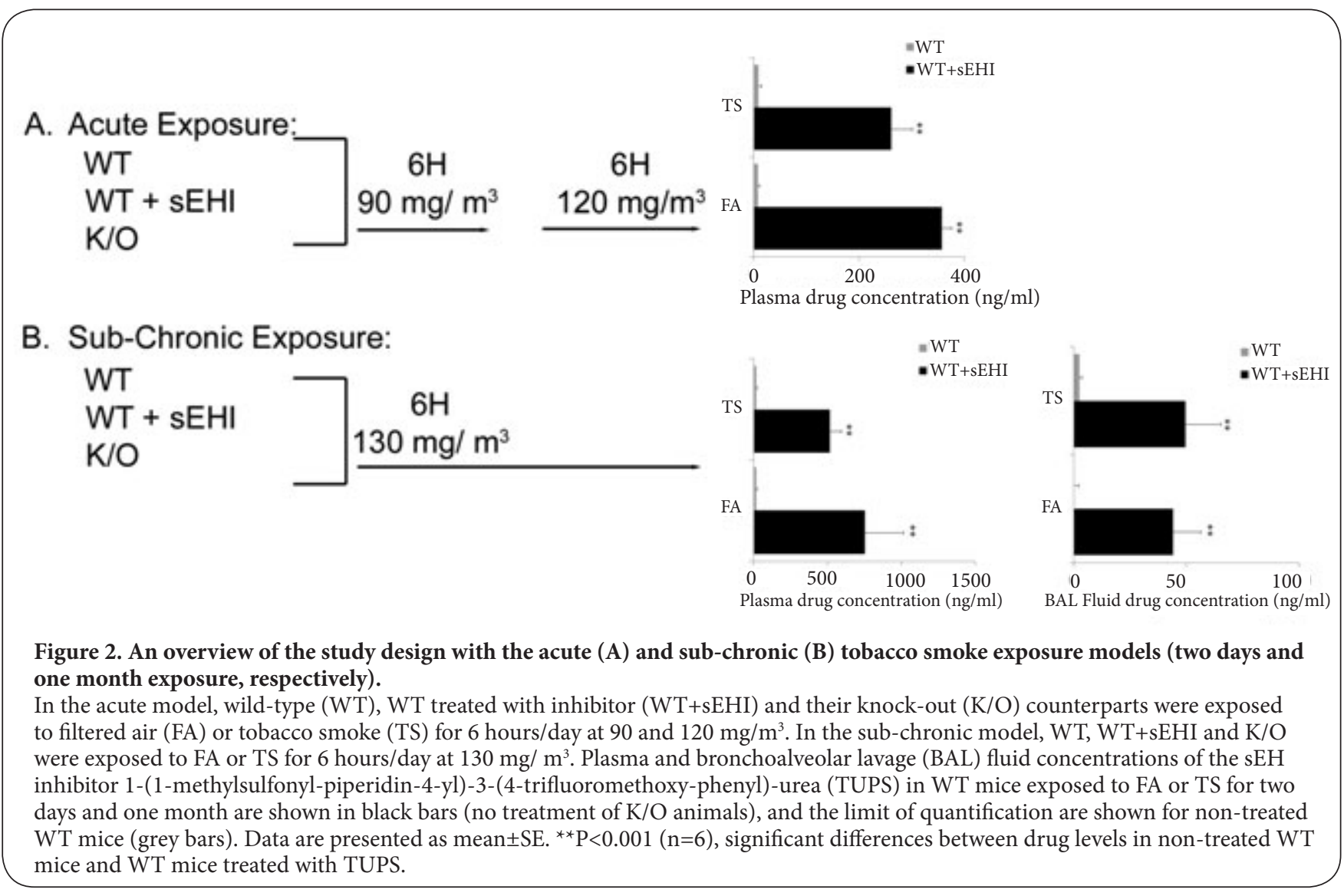


Nording et al. Journal of Metabolomics 2015,

http://www.hoajonline.com/journals/pdf/2059-0008-1-1.pdf

doi: $10.7243 / 2059-0008-1-1$

through centrifugation for 10 minutes at $400 \times \mathrm{g}$, and stored at $-20^{\circ} \mathrm{C}$ until analysis.

\section{Bronchoalveolar lavage fluid}

Established protocols were followed for collection of BAL fluid [27] for the analysis of cell numbers, and oxylipin profiling. Briefly, the trachea was cannulated, and the right lung lobes were sequentially lavaged with $\mathrm{Ca}^{2+} / \mathrm{Mg}^{2+}$-free phosphatebuffered saline (PBS, pH 7.4) or Hank's Balanced Salt Solution (Invitrogen, Carlsbad, CA) in four aliquots. The volume of each aliquot was equal to $35 \mathrm{ml} / \mathrm{kg}$ body weight (approximately $90 \%$ of total lung capacity). Each aliquot was instilled into the lungs three times before final collection. The BAL fluid was immediately centrifuged at $250 \times \mathrm{g}$ for $10 \mathrm{~min}$ at $4^{\circ} \mathrm{C}$ to pellet cells. The cell pellet was then resuspended in PBS (Fisher Scientific, Pittsburgh, PA), and the cells were counted with a hemocytometer.

\section{TUPS extraction and analysis}

The potent sEHI TUPS was analyzed in plasma according to established protocols [25]. Briefly, samples were liquid-liquid extracted with $200 \mu \mathrm{l}$ ethyl acetate [28], and the collected organic phase was dried and re-dissolved in a methanol solution. Quantitation of TUPS was achieved by LC-MS/MS analysis.

\section{Bioactive lipid profiling}

The bioactive lipid profiling of oxylipins in BAL fluid and plasma was done in accordance with previously described protocols [29]. Briefly, oxylipins were isolated by solid phase extraction (Waters Oasis HLB cartridges, Waters Corporation, Milford, MA), re-dissolved in methanol standard solution and quantified using LC-MS/MS analysis. Standard curves for each measured oxylipin were used in calculating the individual oxylipin concentrations.

\section{PCR analysis}

Total mRNA was isolated from middle lobes by using Invitrogen PureLink RNA mini kit (Invitrogen, Carlsbad, CA). Total mRNA was converted to CDNA by the High-Capacity cDNA Reverse Transcription kit (Applied Biosystems, Foster City, CA). qRT-PCR was performed with the Fast SYBR Green Master Mix (Applied Biosystems, Foster City, CA). Samples were run in triplicate with an Applied Biosystems 7500 Fast instrument (Foster City, CA). The primer sequences for each gene are listed in Supplementary Table $\mathbf{S 5}$. The relative quantification of mRNA transcripts was carried out by the delta $C_{\mathrm{T}}$ method. The amount of target normalized to an endogenous reference (beta actin) were presented as fold increase to its control (WT sham). The $\Delta \Delta C_{T}$ was then used to calculate the approximate fold difference, $2^{\Delta \Delta C T}$.

\section{Statistical analysis}

All data were calculated as mean \pm SEM. Univariate comparisons between experimental groups were made by Student's $t$-test. A $P$-value of 0.05 or less was considered significant if nothing else is stated. Multivariate analysis using SIMCA V.13 (Umetrics, Umeå, Sweden) evaluated relationships among experimental groups with regard to epoxide/diol ratios by principal component analysis (PCA) [30]. Prior to PCA, epoxide/ diol ratios were log transformed, scaled to unit variance, and mean-centered. Two principal components were calculated. Effects of TS exposure, sEHI, and sEH K/O strain for PCR analysis were assessed by multi-factor analysis of variance (ANOVA). Differences among experimental groups were examined by using one-way ANOVA followed by Bonferroni post hoc test.

\section{Results}

\section{TUPS plasma and BAL fluid concentrations}

As expected, concentrations of the sEHI TUPS in plasma (Figure 2) were significantly elevated in all treated mice. Lower concentrations of TUPS $(1.5 \mathrm{ng} / \mathrm{ml}$, corresponding to the quantification limit) were measured in WT alone (Figure 2). The higher TUPS levels in plasma at one month compared to two days exposure samples indicate slight accumulation of drug with time but that it quickly reaches a steady state (Figures 2A and 2B). No significant levels of TUPS were measured in BAL fluid at two day exposure (data not shown), only one month later around $50 \mathrm{ng} / \mathrm{ml}$ TUPS was measured in BAL fluid (Figure 2B).

\section{Oxylipin BAL fluid and plasma concentrations}

Measured oxylipins and their abbreviations are found in Figure 1. Total concentrations of oxylipins in BAL fluid (Supplementary Tables S1 and S2) were significantly lower than in plasma (Supplementary Table S3 and S4). In BAL fluid, sub-chronic exposure to TS induced a reduction in total oxylipin levels in the WT mice, but not WT treated with sEHI or K/O mice (Supplementary Table S2). While total epoxide levels, as well as epoxide fractions, were higher in BAL fluid of sham exposed to TUPS treated and K/O mice, compared to WT mice. After acute TS exposure, elevated epoxide of arachidonic acid (12(13)-EpOME) were observed in mice treated with sEHI and $\mathrm{K} / \mathrm{O}$ (Supplementary Tables S1). Interestingly, oxylipins derived from the LOX-pathway dominated the profiles (Figure 3). In general, LOX-, COX- and CYP-dependent oxylipin concentrations differed between BAL fluid and plasma with lower COXfractions and higher CYP-fractions in plasma air exposure. Plasma oxylipin concentrations show a remarkable increase in epoxide levels in TUPS treated mice and K/O mice compared to WT mice, independent of exposure (Supplementary Table S3 and S4).

In Figure 3, fractions of the three major fatty acid catabolic pathways are shown in BAL fluid and plasma from acute and sub-chronic TS and sham exposed mice. In general, sub-chronic TS exposure caused a shift in BAL fluid oxylipin composition in comparison to acute TS exposure, with a more prominent dominance of LOX-derived metabolites after a prolonged exposure time, while plasma oxylipin composition showed a more stable pattern over time (Figure 3 ). Acute and sub- 
Nording et al. Journal of Metabolomics 2015,

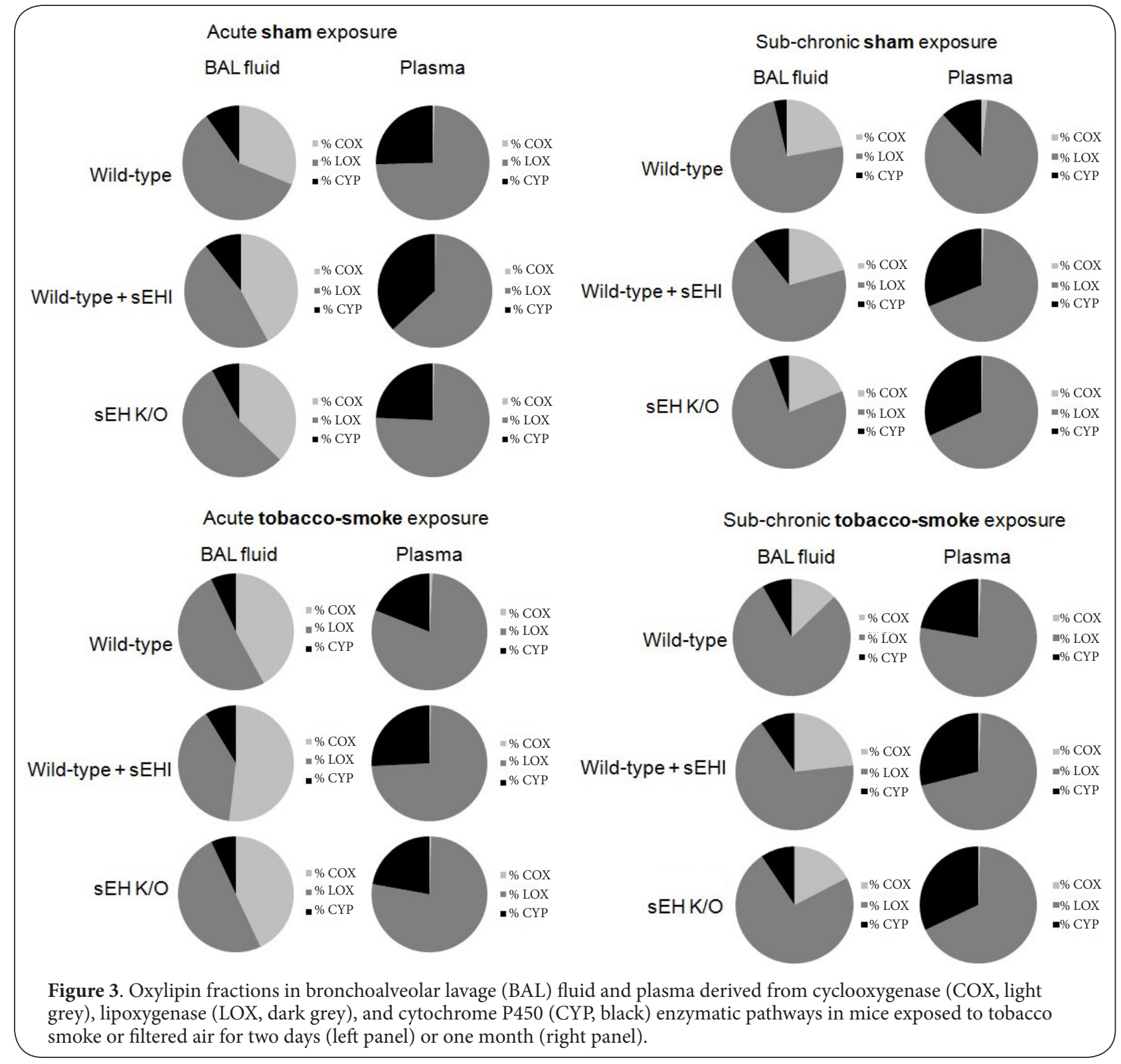

chronic sham exposure show similar oxylipin compositions in BAL fluid with LOX-derived metabolites dominating, followed by COX- and CYP- derived metabolites (Figure 3). While in plasma, the LOX-derived metabolites are dominating followed by metabolites from the CYP pathway and to a lesser extent from the COX pathway (Figure 3 ).

\section{Effects of the sEHI TUPS on TS exposure-induced cell infiltration}

After two days of TS exposure, the number of infiltrated cells in BAL fluid was significantly increased as compared to filtered air exposed mice $(137,761 \pm 27,947$ vs. $34,935 \pm 5,967$ total BAL fluid cells, respectively). Accordingly, a 3-fold change was persisted after one month of TS exposure (from 12,596 $\pm 3,601$ to $40,020 \pm 18,036$ BAL fluid cells after TS exposure). Both $\mathrm{K} / \mathrm{O}$ mice and TUPS treated mice evidenced a significant lower degree of cell infiltration as compared to TS exposed WT mice after two days of TS, 3-fold and 2-fold lower in K/O mice or WT treated with sEHI, respectively $(49,539 \pm 10,026$ and $79,922 \pm 17,239$ BAL fluid cells, respectively). Same fold decrease persisted after one month TS exposure of K/O mice and WT mice after TUPS treatment $(14,987 \pm 3,765$ and $26,859 \pm 8,137$ total BAL fluid cells, respectively). Cell differentials evidenced a significant elevation of neutrophils after one month of TS exposure, an elevation which was reduced to a significant extent (4-fold lower) in K/O mice (from 334 183 neutrophils in WT to $81 \pm 21$ neutrophils in BAL fluid of K/O mice), and 3-fold lower in WT mice treated with sEHI (111 134 neutrophils 
Nording et al. Journal of Metabolomics 2015,

http://www.hoajonline.com/journals/pdf/2059-0008-1-1.pdf

doi: 10.7243/2059-0008-1-1

in BAL fluid). Macrophages showed similar patterns as total cell numbers $(35,729 \pm 15,604$ to $15,534 \pm 3,253$ macrophages in K/O BAL fluids).

\section{Effects of TUPS on TS exposure-induced BAL fluid epoxide to diol ratios}

BAL fluid LOX-, COX- and CYP-dependent oxylipin concentrations are found in Supplementary Tables S1 and S2. Among the epoxides, only 12(13)-EpOME concentrations in both TUPS and K/O mice were elevated in both filtered air and TS exposure experiments (Supplementary Table S1). Analyzing the ratios of epoxide to diols, after two days of TS exposure, a significant increase in 9,10-EpOME to diol ratio was detected in the BAL fluid from WT mice (Figure 4A). Inhibition of sEH both pharmacologically and genetically showed no advantage on epoxide to diol ratio in BAL fluids. Interestingly, 9(10)-EpOME to 9,10-DiHOME ratios showed a significant decrease after one month exposure to TS only in WT mice. No change in this ratio was seen in TUPS treated or K/O mice (Figure 4B). Furthermore, no significant changes in the 12(13)-EpOME to 12,13-DiHOME ratio were seen before or after TS exposure (Figure 4C). Overall, results for epoxide to diol ratios in BAL fluid were inconsistent.

\section{Effects of TUPS on TS exposure-induced plasma epoxide to diol ratios}

The bioactive lipid profiling of plasma covered a broad range of epoxides and diols derived from LA (Figure 5), ARA (Figure 6), ALA and EPA (Figure 7) and DHA (Figure 8). As expected, the LA epoxide to diol ratios were in general significantly elevated after treatment with $\mathrm{sEHI}$, as well as in $\mathrm{K} / \mathrm{O}$ mice compared to WT mice, both exposed to TS and filtered air (Figure 5). TS exposure induced a significant increase in the 9(10)-EpOME/ DiHOME ratio after two days of exposure (Figure $5 \mathrm{~A}$ ), but not after one month exposure (Figure 5C). However, K/O mice demonstrated a decrease in this ratio after one month of exposure, but not after two days. This was also true for the 12(13)-EpOME/DiHOME ratio in K/O mice exposed to tobacco smoke for two days (Figures 5B and 5D). The inconsistency in the epoxide to diol ratios after one month of TS exposure is a result of a massive release of diols in the plasma that drives this value (Supplementary Table S4).

Analysis of ARA epoxide to diol ratios is shown in Figure 6. There was a higher degree of significant changes after two days of exposure (Figures 6A-6D) than after one month of exposure (Figures $6 \mathrm{E}-6 \mathrm{H}$ ). The general trend after two days of exposure was increased epoxide to diol ratios in all of the four ARA-epoxides/diols after treatment compared to nontreated mice, an increase that was further induced in $\mathrm{K} / \mathrm{O}$ mice. In mice exposed for one month, the only significant increase was found in the K/O 8(9)-EET/DHET and K/O 14(15)-EET/DHET ratios (Figures $6 \mathrm{~F}$ and $6 \mathrm{H}$ ).

The ALA epoxide to diol ratio was only detected after two days of exposure (Figure 7A). In accordance with the two days

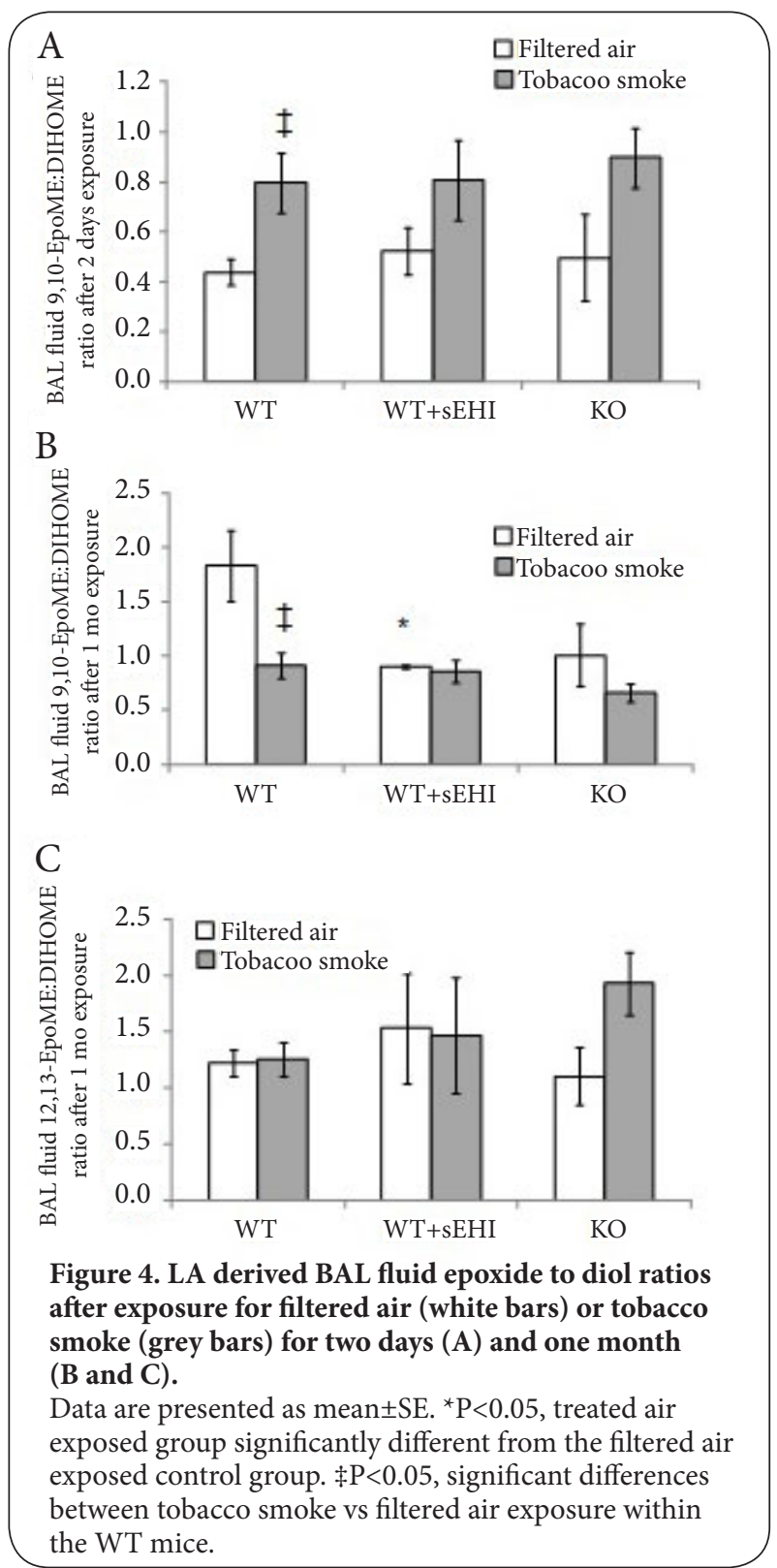

ARA epoxide to diol ratios, it was increased after treatment, and further increased in K/O mice (Figure 7A). The EPA epoxides and diols were only analyzed in mice exposed for one month (Figure 7B). The 17(18)-EpETE/DiHETE ratio was significantly elevated both after treatment and in K/O mice. The DHA epoxides and diols were also only analyzed in mice exposed for one month (Figure 8). Three of the ratios (10(11)-EpDPE/ DiHDPE, 13(14)-EpDPE/DiHDPE, and 16(17)-EpDPE/DiHDPE) were significantly decreased in WT mice exposed to TS compared to filtered air. Two of the ratios were significantly decreased after treatment (Figures $8 \mathrm{~A}$ and $8 \mathrm{~B}$ ), while one was significantly increased (Figure 8D). Furthermore, all four DHA epoxide to diol ratios were significantly increased in $\mathrm{K} / \mathrm{O}$ vs. WT mice exposed to TS (Figure 8). 
A

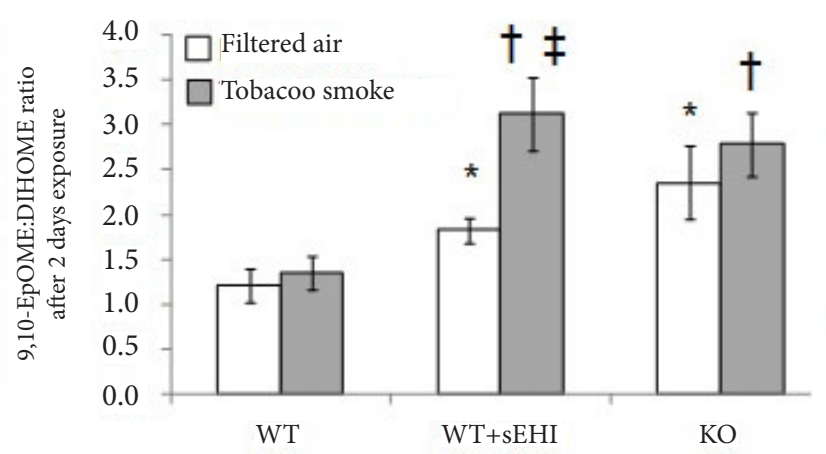

B

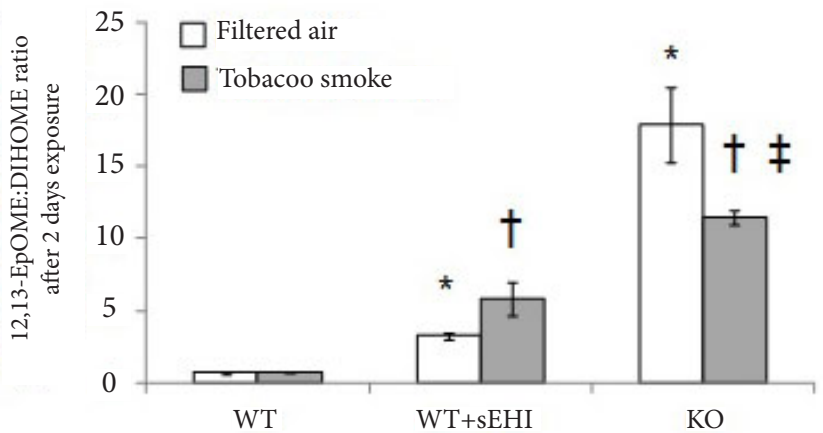

C

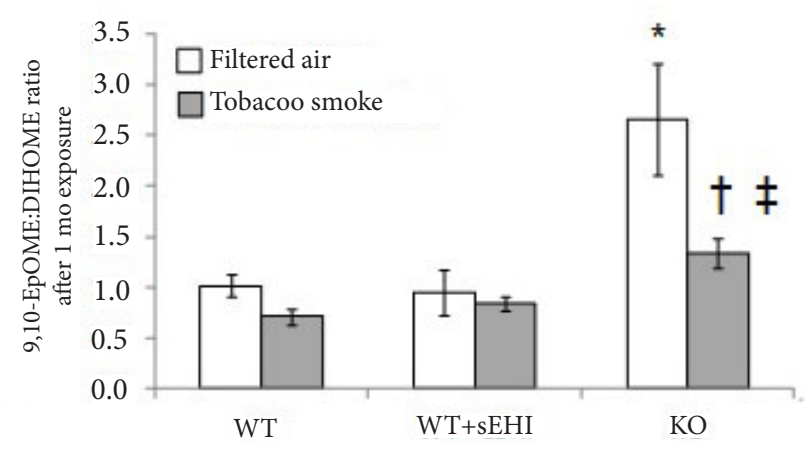

$\mathrm{D}$

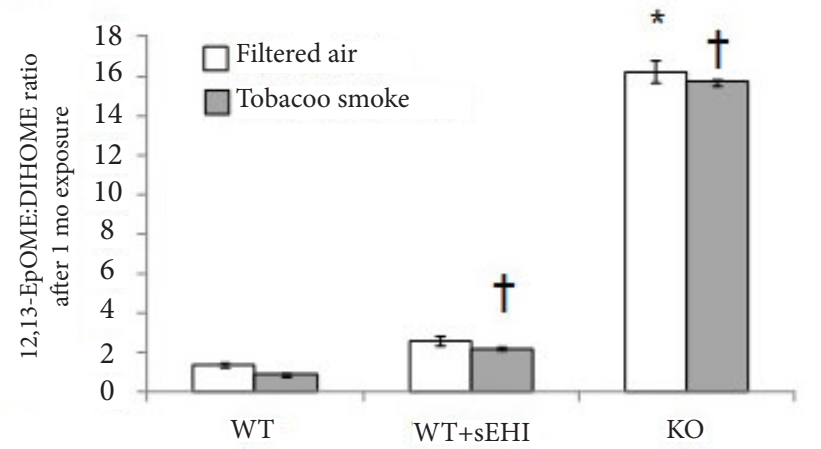

Figure 5. LA derived plasma epoxide to diol ratios after exposure to filtered air (white bars) or tobacco smoke (grey bars) for two days (A and B) and one month (C and D).

Data are presented as mean \pm SE. ${ }^{*} \mathrm{P}<0.05$, treated and $\mathrm{K} / \mathrm{O}$ filtered air exposed groups significantly different from the filtered air exposed control group. $\uparrow \mathrm{P}<0.05$ treated and $\mathrm{K} / \mathrm{O}$ tobacco smoke exposed groups significantly different from the tobacco smoke exposed control group. $\ddagger \mathrm{P}<0.05$, significant differences between tobacco smoke and filtered air exposure within the treated mice and K/O mice, respectively.

A summary of plasma LOX-, COX- and CYP-dependent oxylipin concentrations are found in Supplementary Table S3 and S4. Overall, plasma concentrations of epoxides from regioisoforms of LA, ARA, or ALA showed a significant increase in both TUPS-treated and K/O mice (Supplementary Table S3). These higher concentrations of epoxides are maintained after one month exposure to TS (Supplementary Table S4).

\section{Multivariate analysis of epoxide to diol ratios}

In order to comprehend the relation between the epoxide/ diol ratios in the different exposure and treatment groups, PCA was used. Two models with two principal components each was calculated, one for the acute exposure $\left(R^{2} X=0.909\right.$, $\left.Q^{2}=0.722\right)$ and one for the sub-chronic exposure $\left(R^{2} X=0.859\right.$, $\left.\mathrm{Q}^{2}=0.569\right)$. Only ratios measured in all samples were included in the model. The score plot (Figure 9) revealed the largest variation in the first component (horizontal axis) among samples from WT mice (to the left) and K/O mice (to the right). The mice treated with the potent sEHI TUPS were clustering closer to the $\mathrm{K} / \mathrm{O}$ animals in the acute model driven mainly by principle component one (Figure $9 \mathrm{~A}$ ), compared to the sub-chronic model (Figure 9B). The epoxide/diol ratios mainly responsible for the separation along the first component in both models were 14(15)-EET/DHET and 12(13)-EpOME/ DiHOME, suggesting that these epoxides and diols are the best markers for drug target engagement, independent of exposure regiment.

Effects of TUPS on TS exposure-induced gene expression levels of VEGFa and TNFa in lung homogenate

Levels of mRNA expression of pro-inflammatory gene products TNFa and VEGFa were measured in whole middle lung homogenates. Upon TS exposure, no differences in the mRNA expression of TNFa were detected in WT mice (Figure 10A). Interestingly, in both TUPS-treated WT mice and K/O mice, TNFa mRNA expression was significantly decreased in both exposure regiments (Figure 10A). These data may suggest that while sub-chronic TS exposure is not sufficient to in- 

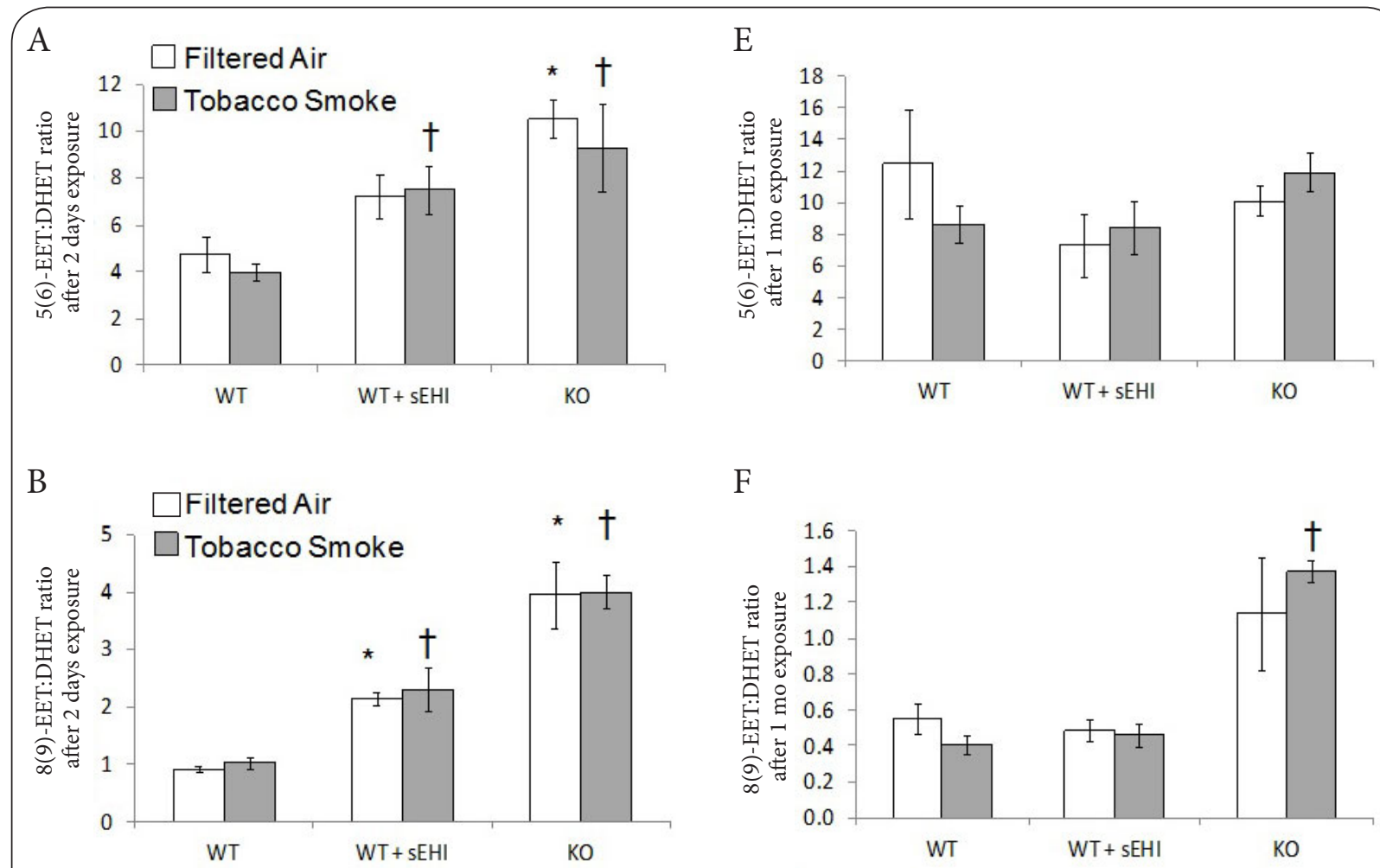

F
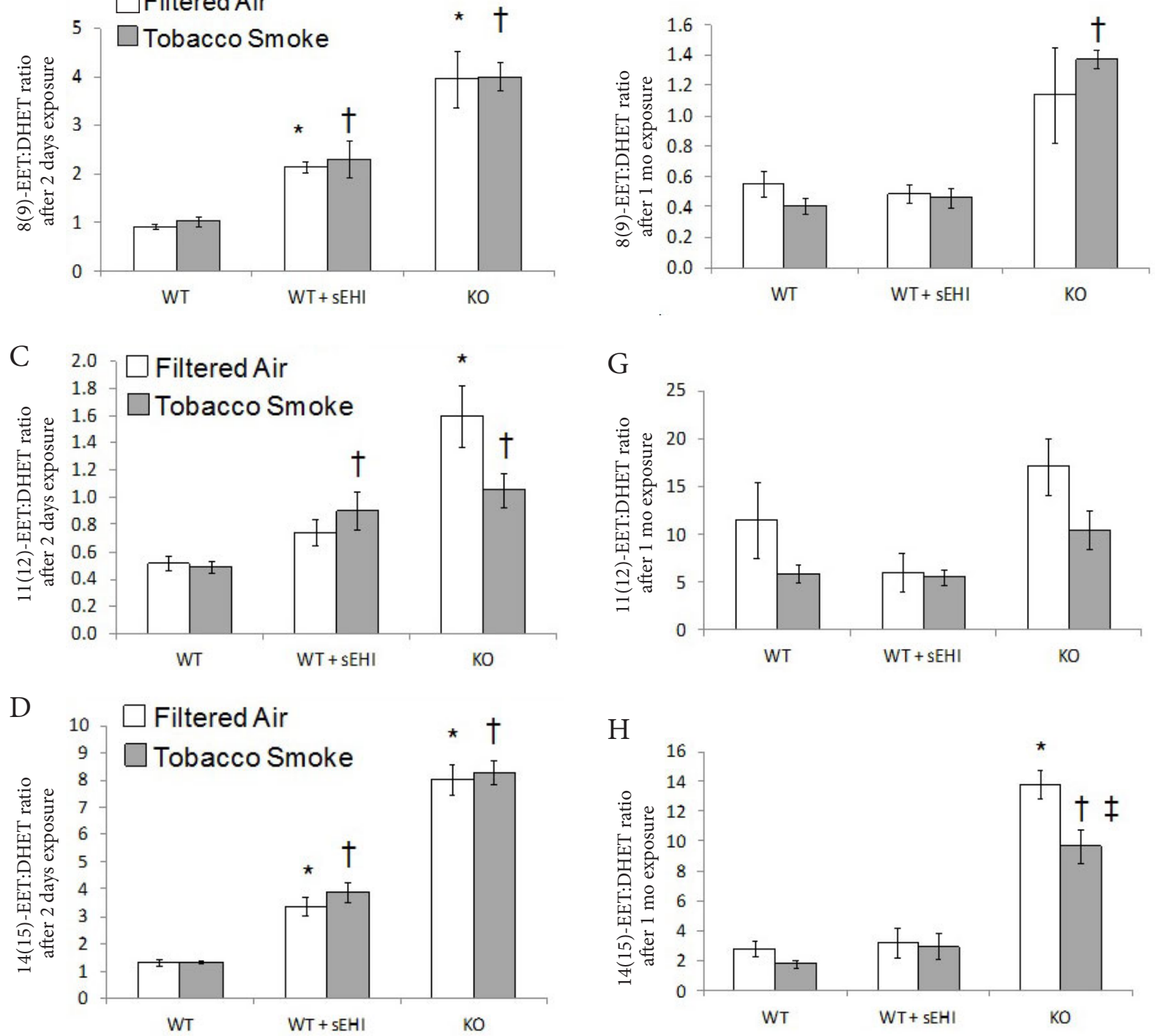

Figure 6. ARA derived plasma epoxide to diol ratios after exposure to filtered air (white bars) or tobacco smoke (grey bars) for two days (A-D) and one month (E-H).

Data are presented as mean \pm SE. ${ }^{\star} \mathrm{P}<0.05$, treated and $\mathrm{K} / \mathrm{O}$ filtered air exposed groups significantly different from the filtered air exposed control group. $\uparrow \mathrm{P}<0.05$ treated and $\mathrm{K} / \mathrm{O}$ tobacco smoke exposed groups significantly different from the tobacco smoke exposed control group. $\$ \mathrm{P}<0.05$, significant differences between tobacco smoke and filtered air exposure within the K/O mice. 


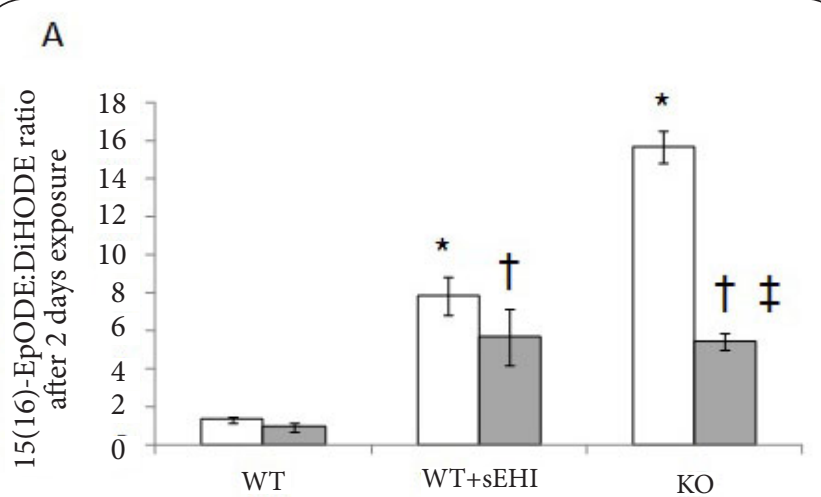

B

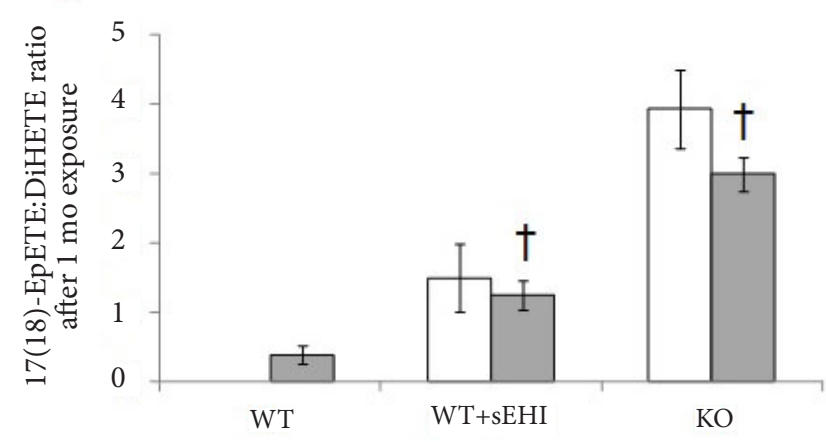

Figure 7. ALA (A) and EPA (B) derived plasma epoxide to diol ratio after exposure to filtered air (white bars) or tobacco smoke (grey bars) for two days or one month. 17(18)-EpETE was not detected in WT mice exposed to filtered air. ${ }^{\star} \mathrm{P}<0.05$, treated and $\mathrm{K} / \mathrm{O}$ filtered air exposed groups significantly different from the filtered air exposed control group. $\uparrow \mathrm{P}<0.05$ treated and $\mathrm{K} / \mathrm{O}$ tobacco smoke exposed groups significantly different from the tobacco smoke exposed control group. $\ddagger \mathrm{P}<0.05$, significant differences between tobacco smoke and filtered air exposure within the K/O mice.

duce pro-inflammatory gene expression changes in whole lung homogenates, the basal mRNA expression levels of this mediator is decreased when either SEH is inhibited or deleted (Figure 10A).

No change in VEGF mRNA expression was found in lung homogenates after sub-chronic TS exposure in WT mice, but a significant increase in VEGF mRNA expression was detected in TUPS-treated mice followed by TS exposure (Figure 10B). This pattern was also evident in K/O mice, although basal expression of VEGF was high in sham exposed mice (Figure 10B). This observation may indicate why we observed lower number of infiltrated cells in BAL fluid of both TUPS treated and $\mathrm{K} / \mathrm{O}$ mice.

\section{Discussion}

In accordance with reported protective properties of EETs in inflammation, a high EET/DHET ratio is thought to be desirable, which was induced for some treatment groups, but not for all. Other epoxide/diol ratios were also affected, suggesting a wider role for $\mathrm{sEH}$ involving more fatty acid precursors besides ARA. TS exposure-induced decrease in plasma epoxide/diol ratios from WT mice was evident to a significant extent in three of the measured ratios, and they were all derived from DHA. In K/O mice, TS exposure-induced decrease in plasma epoxide/diol was evident to a significant extent in four of the measured ratios, two derived from LA, one from ARA, and one from ALA. This suggests that TS exposure has a negative effect, at least in part, on epoxide/diol ratios, which can be restored by sEH-intervention, either by pharmacological inhibition or through gene disruption. The anti-inflammatory effect of $s E H$ inhibition in another model was demonstrated in the study of Smith et al, in which $\mathrm{SEH}$ inhibiton was found to attenuate the inflammation caused by acute TS exposure in spontaneously hypertensive rats [7]. EETs play a central role in the inflammatory process. For example, elevated levels of EETs due to $\mathrm{sEH}$ inhibition prevented the expression of adhesion molecules including E-selectin, vascular cell adhesion molecule 1, and intercellular adhesion molecule 1, which facilitate leukocyte adhesion to the vascular wall to promote inflammation [31]. In order to further elucidate the role of sEH in TS exposureinduced inflammation, mechanistic studies highlighting how $\mathrm{sEH}$ inhibition regulates inflammation are needed.

The effectiveness of the sEHI TUPS in reducing pulmonary inflammation from tobacco smoke is shown by the dramatic reduction in cell numbers detected in BAL fluid, particularly in the acute model of inflammation. Furthermore, the decrease in neutrophil numbers in the sub-chronic model, both in $\mathrm{K} / \mathrm{O}$ animals and after TUPS treatment, support attenuation of TS-induced neutrophil influx by TUPS. The higher expression of VEGF along with a reduction of the pro-inflammatory mediator, TNFa, expression in whole middle lung extract, can be explained by the lower number of infiltrated BAL fluid cells. VEGF and its receptor mediate survival signaling that is critical in endothelial cell survival [32] and wound healing. Previous studies have shown that emphysema patients have decreased VEGF expression along with increased endothelial cell death [33]. Furthermore, it has been shown that tobaccosmoke exposure significantly decreases VEGF levels and its downstream signaling in mouse and rat lungs [34,35]. Here, we show that sub-chronic smoke exposure alone was not sufficient to induce changes in VEGF expression, but the basal levels of VEGF may indicate higher survival rate of endothelial cells and healthy vasculature.

The ratio of lipid epoxides to their corresponding diols is commonly used as qualitative indicator of target engagement for $\mathrm{sEHI}$ since one expects the substrate epoxides to increase and the corresponding diol products to decrease when the sEH is inhibited. The high abundance of oxylipins in the blood from the 18:2 lipid linoleate is particularly attractive as an indicator of target engagement due to their ease of analysis as recently shown in a study on cardiac function [36]. In general, this study supports the qualitative use of epoxide to diol ratios to indicate target engagement. This trend is most 
A

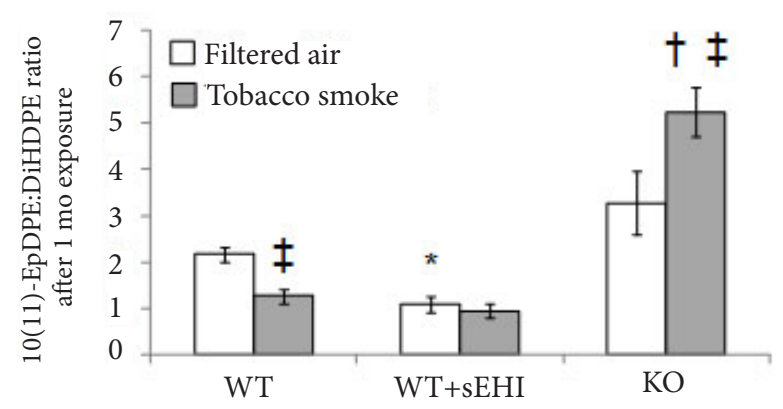

B

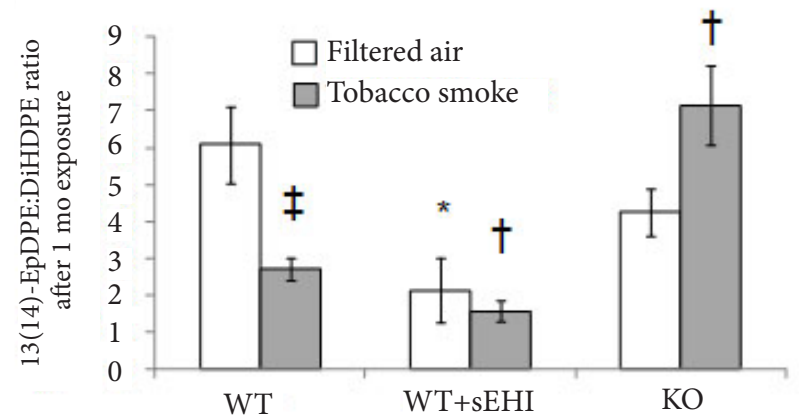

C

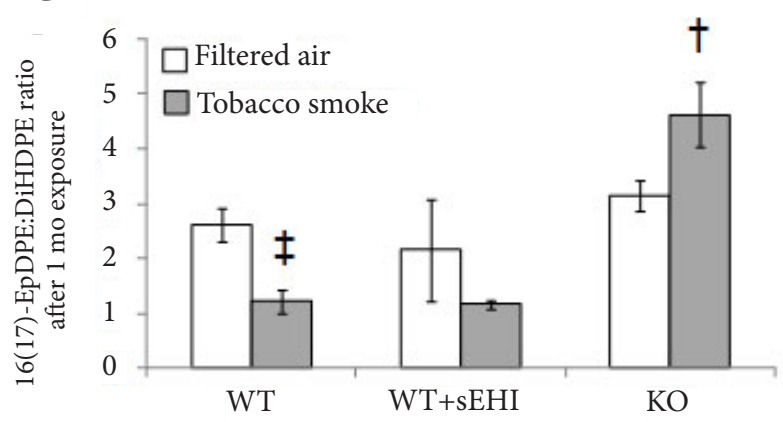

$\mathrm{D}$

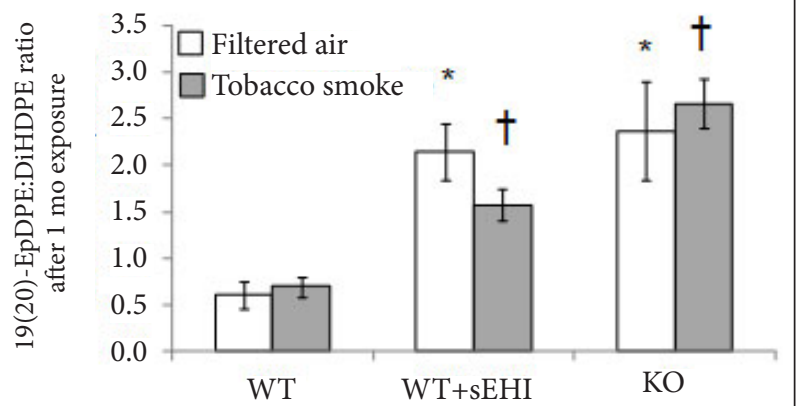

Figure 8. DHA derived plasma epoxide to diol ratio after exposure to filtered air (white bars) or tobacco smoke (grey bars) for one month.

${ }^{*} \mathrm{P}<0.05$, treated and $\mathrm{K} / \mathrm{O}$ filtered air exposed groups significantly different from the filtered air exposed control group. $\dagger \mathrm{P}<0.05$ treated and $\mathrm{K} / \mathrm{O}$ tobacco smoke exposed groups significantly different from the tobacco smoke exposed control group. $\ddagger \mathrm{P}<0.05$, significant differences between tobacco smoke and filtered air exposure within the WT and K/O mice, respectively.

clearly seen with genetic $\mathrm{K} / \mathrm{O}$ animals with high ratios. Our data suggest that even the high levels of TUPS observed in the plasma, which are far greater than the in vitro half-maximal inhibitory levels (TUPS $I C_{50}$ on recombinant murine $\mathrm{SEH}=9$ nM) [37], were not sufficient to completely inhibit the $s E H$. This could be due to some enzyme present in tissues which is poorly reached by the TUPS. Furthermore, low levels of EETs in BAL fluids are detectable using expensive, laborious and highly sensitive LC-MS/MS methods. We believe that the ratio of fatty acid epoxides/diols provides a much better reflection of these metabolites in a temporal and spatial manner. It is however, captured temporal changes that might be followed by cellular changes. In this regards, unlike chronic TS exposure, it could be that in acute model, the lungs are still healthy and trying to 'fight' against TS exposure by an increase in fatty acid metabolites.

Numerous factors contribute to the qualitative nature of the lipid epoxide/diol ratio as an indicator of drug target engagement of $\mathrm{sEHI}$. First, epoxide levels are regulated by release of epoxide containing lipids from more stable pools, release of lipid substrate, and rate of biosynthesis, all of which can vary. For example, some inhibitors of phosphodiesterase can alter the ratio of lipid epoxides and diols dramatically [38].
Secondly, the diols are rapidly conjugated with glucuronic acid and removed by filtration and active transport [39]. Thirdly, there is a massive difference in polarity between the lipid epoxide and their diols placing them in largely different in vivo pools. Finally, both epoxides and diols are subject to many other reactions common to fatty acids including chain elongations and beta oxidation, P450 oxidation and peroxidation, reincorporation into phospholipids and other pathways. Thus, it is not surprising that the epoxide to diol ratios often has more qualitative than quantitative value.

\section{Conclusions}

Our study demonstrates a novel, potent and selective soluble epoxide hydrolase inhibitor that has good aqueous solubility with high oral bioavailability in mice. As a result of this inhibition, a shift in substrate to product ratio is observed. Furthermore, in this in vivo study, we show that inhibition of soluble epoxide hydrolase results in down regulation of an inflammatory response induced by acute or chronic tobacco smoke exposure as was observed from total cell, neutrophils and macrophage lung cell infiltration. This observation was, for the first time, supported by genetically modified mice that lack the Ephx2 gene. Furthermore, here we demonstrate 

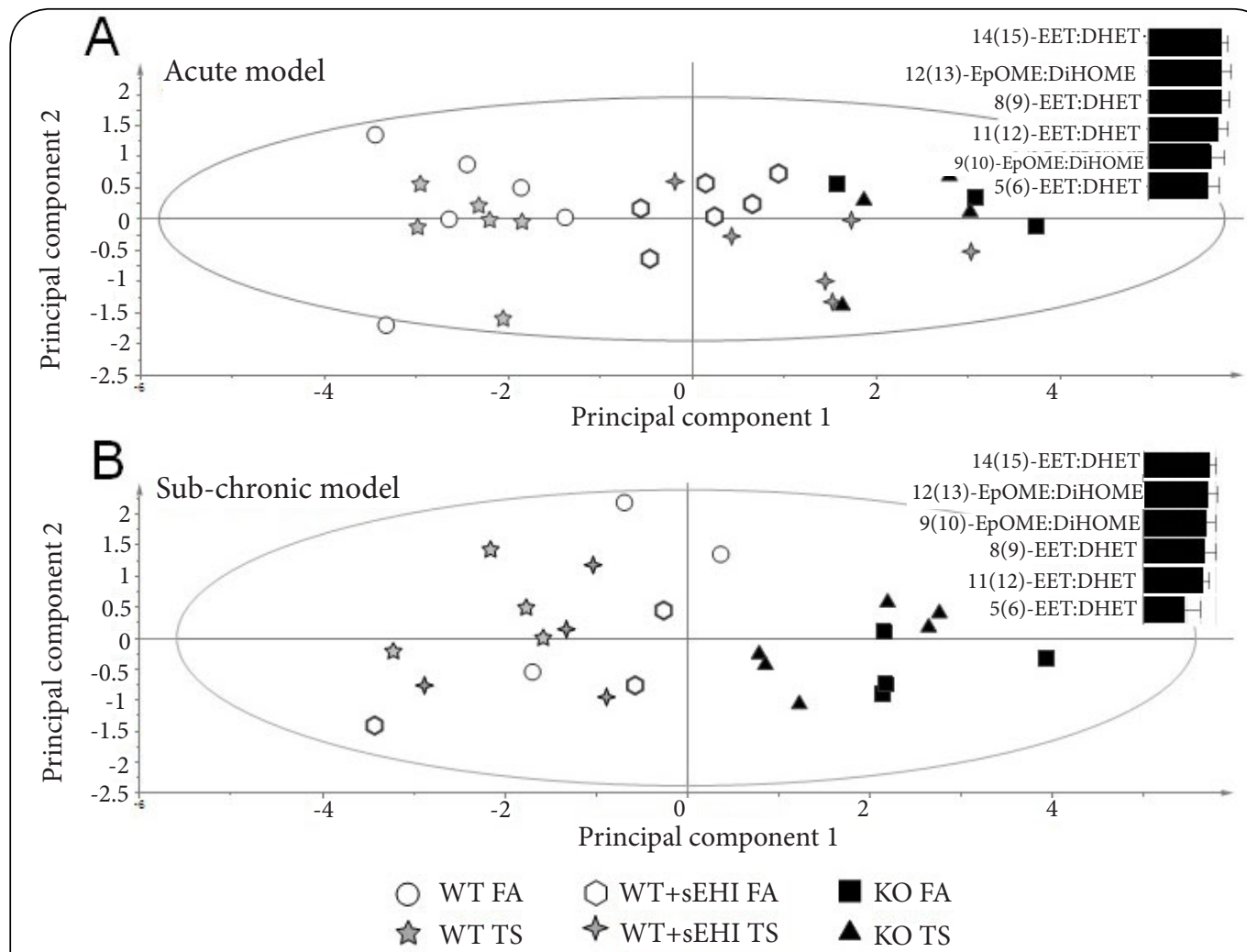

Figure 9. Score plot showing relations between $\mathrm{WT}$ and $\mathrm{K} / \mathrm{O}$ mice exposed to filtered air (FA) or tobacco smoke (TS) for two days (A) and one month (B), and WT mice treated with the sEH inhibitor (sEHI) TUPS during exposure.

Bar graphs show the contribution of different plasma epoxide/diol ratios to the separation along the horizontal axis.

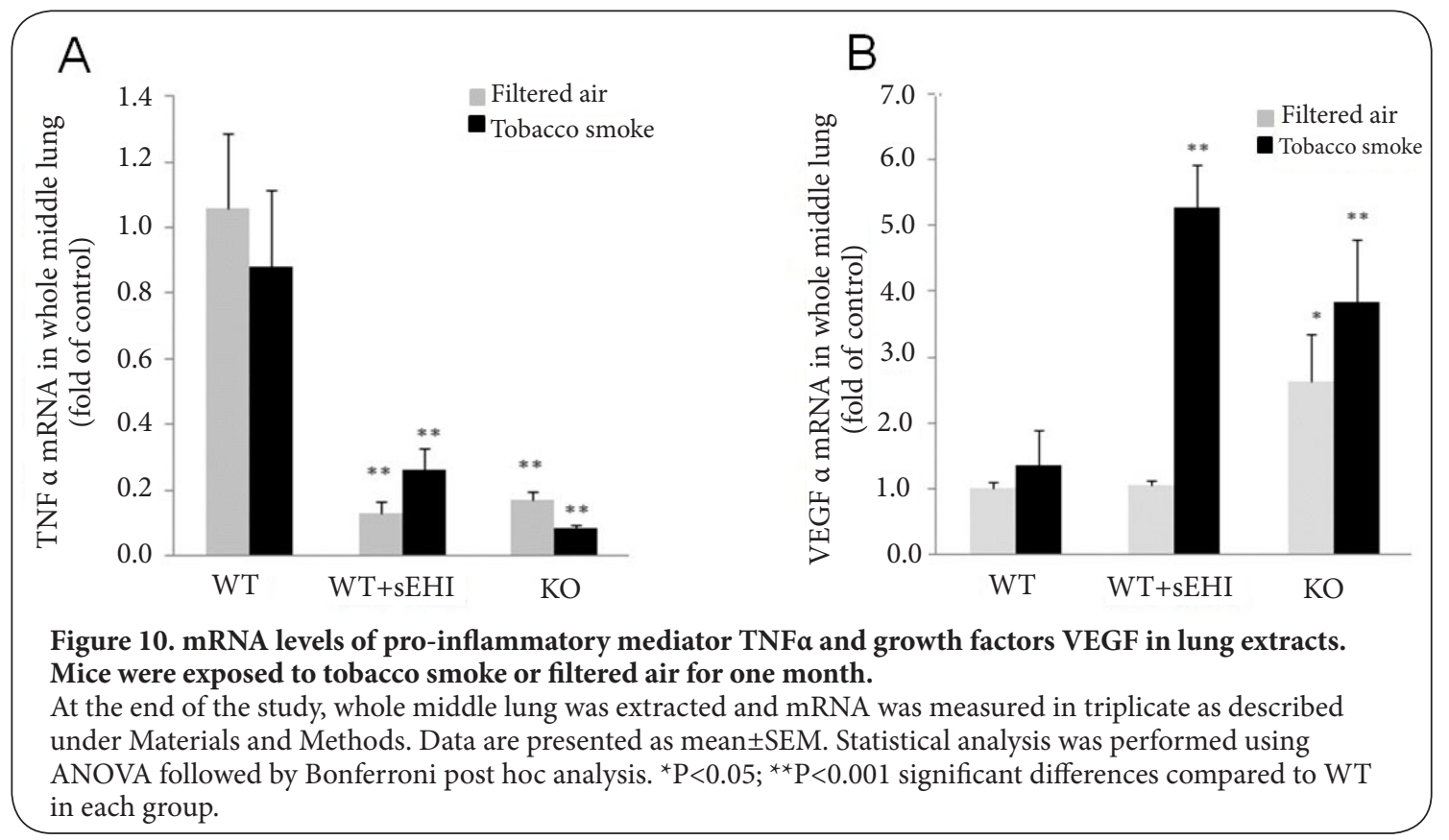


Nording et al. Journal of Metabolomics 2015,

http://www.hoajonline.com/journals/pdf/2059-0008-1-1.pdf

doi: 10.7243/2059-0008-1-1

a comprehensive profile analysis of omega- 3 and 6 fatty acid metabolites in regard to tobacco smoke exposure, lung inflammation and soluble epoxide hydrolase inhibition. In accordance to recent studies published by Yang et al., [40], showing that sEH inhibition attenuates inflammation and airway hyperresponsiveness in mice [40] and Podolin et al., [41], showing that inhibition of EETs to DHETs conversion also result in down-regulation of the inflammatory response induced by repetitive exposure to cigarette smoke. While the mechanism of action is not reported, supporting evidences from previous studies show that the anti-inflammatory effects of sEHI are believed to occur primarily as a result of the attenuation of the metabolism of EETs to DHETs [41]. We clearly see this trend here in this study. The decrease in TNF-a gene expression in lung homogenates reported here also shed some light on the mechanism of action by which sEHI works. EETs have been reported to inhibit the $\mathrm{NF}-\mathrm{KB}$ signaling pathway, and the subsequent expression of the adhesion molecules, vascular cell adhesion molecule-1 (VCAM-1), intercellular adhesion molecule-1 (ICAM-1), and E-selectin, thereby attenuating leukocyte migration [10]. Similarly, decreases in BAL fluid leukocyte numbers have been reported in the spontaneously hypertensive rat following repetitive smoke exposure concomitant with $\mathrm{sEHI}$ treatment $[7,8]$. Such a mechanism would be consistent with the reduction in BAL fluid leukocytes exhibited by cigarette smoke-exposed mice treated concomitantly with $\mathrm{sEHI}$ [41]. Interestingly, these inhibitors are currently under human study for the evaluation of safety, tolerability, pharmacokinetics (PK) and pharmacodynamics (PD) administered to healthy adult male moderately obese smokers [42]. Finally, our findings demonstrate the ability of $s E H$ to function as a potential pharmaceutical target for the development of therapies preventing or treating COPD.

List of abbreviations

ALA: a-linolenic acid

ARA: Arachidonic acid

BAL: Bronchoalveolar lavage

COPD: Chronic obstructive pulmonary disease

COX: Cyclooxygenase

CYP: Cytochrome P450 monooxygenase

DHA: Docosahexaenoic acid

EET: Epoxyeicosatrienoic acid

EPA: Eicosapentaenoic acid

LA: Linoleic acid

LC-MS/MS: Liquid chromatography coupled

to tandem mass spectrometry

LOX: Lipooxygenase

PCA: Principal component analysis

sEH: Soluble epoxide hydrolase

sEHI: sEH inhibitor

TS: Tobacco smoke

TUPS: 1-(1-methylsulfonyl-piperidin-4-yl)-3-

(4-trifluoromethoxy-phenyl)-urea

TNFa: Tumor necrosis factor alpha

VEGF: Vascular endothelial growth factor

\section{Additional files \\ Supplementary Table S1 \\ Supplementary Table S2 \\ Supplementary Table S3 \\ Supplementary Table S4 \\ Supplementary Table S5}

Competing interests

The authors declare that they have no competing interests.

Authors' contributions

\begin{tabular}{|l|c|c|c|c|c|c|c|c|c|}
\hline Authors' contributions & MLN & JY & LH & VZ & DU & IE & KEP & BDH & AL \\
\hline Research concept and design & $\checkmark$ & -- & -- & -- & -- & -- & $\checkmark$ & $\checkmark$ & $\checkmark$ \\
\hline $\begin{array}{l}\text { Collection and/or assembly } \\
\text { of data }\end{array}$ & $\checkmark$ & $\checkmark$ & $\checkmark$ & $\checkmark$ & $\checkmark$ & $\checkmark$ & $\checkmark$ & $\checkmark$ & $\checkmark$ \\
\hline $\begin{array}{l}\text { Data analysis and } \\
\text { interpretation }\end{array}$ & $\checkmark$ & -- & -- & -- & -- & -- & $\checkmark$ & $\checkmark$ & $\checkmark$ \\
\hline Writing the article & $\checkmark$ & -- & -- & -- & -- & -- & $\checkmark$ & $\checkmark$ & $\checkmark$ \\
\hline Critical revision of the article & $\checkmark$ & $\checkmark$ & $\checkmark$ & $\checkmark$ & $\checkmark$ & $\checkmark$ & $\checkmark$ & $\checkmark$ & $\checkmark$ \\
\hline Final approval of article & $\checkmark$ & -- & -- & -- & -- & -- & $\checkmark$ & $\checkmark$ & $\checkmark$ \\
\hline Statistical analysis & $\checkmark$ & -- & -- & -- & -- & -- & -- & -- & $\checkmark$ \\
\hline
\end{tabular}

Acknowledgement

The study was supported by the Tobacco-Related Disease Research Program (TRDRP) 16KT-0037, and 18XT-0154, NIEHS Grant ES02710, NIEHS Superfund Basic Research Program Grant P42 ES04699, the NIH Metabolomics Center, the American Asthma Foundation \#09-0269, and the Swedish Research Councils Formas, and Vinnova. The funding sources had no role in the design or conduct of the study. Bruce D. Hammock is a George and Judy Marcus Senior Fellow of the American Asthma Society.

Publication history

Editor: Mahendra Pratap Singh, CSIR-Indian Institute of Toxicology Research, India.

Received: 17-Feb-2015 Final Revised: 18-Mar-2015

Accepted: 27-Mar-2015 Published: 04-Apr-2015

\section{References}

1. Balkissoon R, Lommatzsch S, Carolan B and Make B. Chronic obstructive pulmonary disease: a concise review. Med Clin North Am. 2011; 95:1125-41. | Article | PubMed

2. Barnes PJ. Future treatments for chronic obstructive pulmonary disease and its comorbidities. Proc Am Thorac Soc. 2008; 5:857-64. | Article | PubMed

3. Churg A, Wang RD, Tai H, Wang X, Xie C, Dai J, Shapiro SD and Wright JL. Macrophage metalloelastase mediates acute cigarette smoke-induced inflammation via tumor necrosis factor-alpha release. Am J Respir Crit Care Med. 2003; 167:1083-9. | Article | PubMed

4. Hele DJ and Belvisi MG. Novel therapies for the treatment of inflammatory airway disease. Expert Opin Investig Drugs. 2003; 12:5-18. | Article | PubMed

5. Fox JC and Fitzgerald MF. The role of animal models in the pharmacological evaluation of emerging anti-inflammatory agents for the treatment of COPD. Curr Opin Pharmacol. 2009; 9:231-42. | Article | PubMed

6. Barnes NC, Qiu YS, Pavord ID, Parker D, Davis PA, Zhu J, Johnson M, Thomson NC and Jeffery PK. Antiinflammatory effects of salmeterol/ fluticasone propionate in chronic obstructive lung disease. Am J Respir Crit Care Med. 2006; 173:736-43. I Article I PubMed 
7. Smith KR, Pinkerton KE, Watanabe T, Pedersen TL, Ma SJ and Hammock BD. Attenuation of tobacco smoke-induced lung inflammation by treatment with a soluble epoxide hydrolase inhibitor. Proc Natl Acad Sci U S A. 2005; 102:2186-91. | Article | PubMed Abstract | PubMed Full Text

8. Wang L, Yang J, Guo L, Uyeminami D, Dong $\mathrm{H}$, Hammock BD and Pinkerton KE. Use of a soluble epoxide hydrolase inhibitor in smokeinduced chronic obstructive pulmonary disease. Am J Respir Cell Mol Biol. 2012; 46:614-22. | Article | PubMed Abstract | PubMed Full Text

9. Inceoglu B, Schmelzer KR, Morisseau C, Jinks SL and Hammock BD. Soluble epoxide hydrolase inhibition reveals novel biological functions of epoxyeicosatrienoic acids (EETs). Prostaglandins Other Lipid Mediat. 2007; 82:42-9. | Article | PubMed Abstract | PubMed Full Text

10. Node K, Huo Y, Ruan X, Yang B, Spiecker M, Ley K, Zeldin DC and Liao JK. Anti-inflammatory properties of cytochrome $\mathrm{P} 450$ epoxygenase-derived eicosanoids. Science. 1999; 285:1276-9. | Article | PubMed Abstract | PubMed Full Text

11. Jung O, Brandes RP, Kim IH, Schweda F, Schmidt R, Hammock BD, Busse $R$ and Fleming $I$. Soluble epoxide hydrolase is a main effector of angiotensin II-induced hypertension. Hypertension. 2005; 45:759-65. I Article I PubMed

12. Xu D, Li N, He Y, Timofeyev V, Lu L, Tsai HJ, Kim IH, Tuteja D, Mateo RK, Singapuri A, Davis BB, Low R, Hammock BD and Chiamvimonvat $N$. Prevention and reversal of cardiac hypertrophy by soluble epoxide hydrolase inhibitors. Proc Natl Acad Sci U S A. 2006; 103:18733-8. | Article | PubMed Abstract | PubMed Full Text

13. Schmelzer KR, Inceoglu B, Kubala L, Kim IH, Jinks SL, Eiserich JP and Hammock BD. Enhancement of antinociception by coadministration of nonsteroidal anti-inflammatory drugs and soluble epoxide hydrolase inhibitors. Proc Natl Acad Sci U S A. 2006; 103:13646-51. | Article | PubMed Abstract I PubMed Full Text

14. Luria A, Bettaieb A, Xi Y, Shieh GJ, Liu HC, Inoue H, Tsai HJ, Imig JD, Haj FG and Hammock BD. Soluble epoxide hydrolase deficiency alters pancreatic islet size and improves glucose homeostasis in a model of insulin resistance. Proc Natl Acad Sci U S A. 2011; 108:9038-43. | Article | PubMed Abstract | PubMed Full Text

15. Zeldin DC, Moomaw CR, Jesse N, Tomer KB, Beetham J, Hammock BD and Wu S. Biochemical characterization of the human liver cytochrome P450 arachidonic acid epoxygenase pathway. Arch Biochem Biophys. 1996; 330:87-96. | Article | PubMed

16. Zivkovic AM, Yang J, Georgi K, Hegedus C, Nording ML, O'Sullivan A, German JB, Hogg RJ, Weiss RH, Bay C and Hammock BD. Serum oxylipin profiles in IgA nephropathy patients reflect kidney functional alterations. Metabolomics. 2012; 8:1102-1113. | Article | PubMed Abstract I PubMed Full Text

17. Panigrahy D, Edin ML, Lee $C R$, Huang $S$, Bielenberg DR, Butterfield $\mathrm{CE}$, Barnes CM, Mammoto A, Mammoto T and Luria A et al. Epoxyeicosanoids stimulate multiorgan metastasis and tumor dormancy escape in mice. J Clin Invest. 2012; 122:178-91. | Article | PubMed Abstract | PubMed Full Text

18. Ferrara $\mathrm{N}$ and Davis-Smyth $\mathrm{T}$. The biology of vascular endothelial growth factor. Endocr Rev. 1997; 18:4-25. | Article | PubMed

19. Dvorak HF, Brown LF, Detmar M and Dvorak AM. Vascular permeability factor/vascular endothelial growth factor, microvascular hyperpermeability, and angiogenesis. Am J Pathol. 1995; 146:1029-39. | PubMed Abstract | PubMed Full Text

20. Lundstrom SL, Levanen B, Nording M, Klepczynska-Nystrom A, Skold M, Haeggstrom JZ, Grunewald J, Svartengren M, Hammock BD, Larsson BM, Eklund A, Wheelock AM and Wheelock CE. Asthmatics exhibit altered oxylipin profiles compared to healthy individuals after subway air exposure. PLoS One. 2011; 6:e23864. | Article | PubMed Abstract | PubMed Full Text

21. Lundström SL, Yang J and Källberg HJ et al. Allergic asthmatics show divergent lipid mediator profiles from healthy controls both at baseline and following birch pollen provocation. PLOS ONE. 2012; 7:e33780. | Article

22. Lundstrom SL, Balgoma D, Wheelock AM, Haeggstrom JZ, Dahlen SE and
Wheelock CE. Lipid mediator profiling in pulmonary disease. Curr Pharm Biotechnol. 2011; 12:1026-52. | Article | PubMed

23. Nording ML, Yang J, Hegedus CM, Bhushan A, Kenyon NJ, Davis CE and Hammock BD. Endogenous Levels of Five Fatty Acid Metabolites in Exhaled Breath Condensate to Monitor Asthma by High-Performance Liquid Chromatography: Electrospray Tandem Mass Spectrometry. IEEE Sens J. 2010; 10:123-130. | Article | PubMed Abstract | PubMed Full Text

24. Luria $A$, Weldon $S M$, Kabcenell $A K$, Ingraham $R H$, Matera $D$, Jiang $H$, Gill R, Morisseau C, Newman JW and Hammock BD. Compensatory mechanism for homeostatic blood pressure regulation in Ephx2 genedisrupted mice. J Biol Chem. 2007; 282:2891-8. | Article | PubMed Abstract | PubMed Full Text

25. Tsai HJ, Hwang SH, Morisseau C, Yang J, Jones PD, Kasagami T, Kim IH and Hammock BD. Pharmacokinetic screening of soluble epoxide hydrolase inhibitors in dogs. Eur J Pharm Sci. 2010; 40:222-38. | Article | PubMed Abstract | PubMed Full Text

26. Ji CM, Plopper CG, Witschi HP and Pinkerton KE. Exposure to sidestream cigarette smoke alters bronchiolar epithelial cell differentiation in the postnatal rat lung. Am J Respir Cell Mol Biol. 1994; 11:312-20. | PubMed

27. Gossart S, Cambon C, Orfila C, Seguelas MH, Lepert JC, Rami J, Carre P and Pipy B. Reactive oxygen intermediates as regulators of TNF-alpha production in rat lung inflammation induced by silica. J Immunol. 1996; 156:1540-8. | PubMed

28. Liu JY, Tsai HJ, Hwang SH, Jones PD, Morisseau C and Hammock BD. Pharmacokinetic optimization of four soluble epoxide hydrolase inhibitors for use in a murine model of inflammation. BrJ Pharmacol. 2009; 156:284-96. | Article | PubMed Abstract | PubMed Full Text

29. Yang J, Schmelzer K, Georgi K and Hammock BD. Quantitative profiling method for oxylipin metabolome by liquid chromatography electrospray ionization tandem mass spectrometry. Anal Chem. 2009; 81:8085-93. | Article | PubMed Abstract | PubMed Full Text

30. Wold S, Esbensen $\mathrm{K}$ and Geladi P. Principal component analysis. Chemometr Intell Lab. 1987; 2:37-52.

31. Campbell WB. New role for epoxyeicosatrienoic acids as antiinflammatory mediators. Trends Pharmacol Sci. 2000; 21:125-7. | Article I PubMed

32. Gerber HP, McMurtrey A, Kowalski J, Yan M, Keyt BA, Dixit V and Ferrara $N$. Vascular endothelial growth factor regulates endothelial cell survival through the phosphatidylinositol 3'-kinase/Akt signal transduction pathway. Requirement for Flk-1/KDR activation. J Biol Chem. 1998; 273:30336-43. | Article I PubMed

33. Marwick JA, Stevenson CS, Giddings J, MacNee W, Butler K, Rahman I and Kirkham PA. Cigarette smoke disrupts VEGF165-VEGFR-2 receptor signaling complex in rat lungs and patients with COPD: morphological impact of VEGFR-2 inhibition. Am J Physiol Lung Cell Mol Physiol. 2006; 290:L897-908. | Article | PubMed

34. Plataki M, Tzortzaki E, Rytila P, Demosthenes M, Koutsopoulos A and Siafakas NM. Apoptotic mechanisms in the pathogenesis of COPD. Int J Chron Obstruct Pulmon Dis. 2006; 1:161-71. | PubMed Abstract | PubMed Full Text

35. Zhang XY, Zhang C, Sun QY, Li D, Luo RR, Wan ZF, Ye XW, Liu WJ, Rao $\mathrm{SS}$ and Han J. Infliximab protects against pulmonary emphysema in smoking rats. Chin Med J (Engl). 2011; 124:2502-6. | PubMed

36. Morgan LA, Olzinski AR, Upson JJ, Zhao S, Wang T, Eisennagel SH, Hoang B, Tunstead JR, Marino JP, Jr., Willette RN, Jucker BM and Behm DJ. Soluble epoxide hydrolase inhibition does not prevent cardiac remodeling and dysfunction after aortic constriction in rats and mice. $J$ Cardiovasc Pharmacol. 2013; 61:291-301. | Article | PubMed

37. Inceoglu B, Wagner KM, Yang J, Bettaieb A, Schebb NH, Hwang SH, Morisseau C, Haj FG and Hammock BD. Acute augmentation of epoxygenated fatty acid levels rapidly reduces pain-related behavior in a rat model of type I diabetes. Proc Natl Acad Sci U S A. 2012; 109:11390-5. | Article | PubMed Abstract | PubMed Full Text

38. Inceoglu B, Wagner K and Schebb NH. Analgesia mediated by soluble epoxide hydrolase inhibitors is dependent on cAMP. Proc Natl Acad Sci USA. 2011; 108:5093-5097. | Article 
Nording et al. Journal of Metabolomics 2015,

http://www.hoajonline.com/journals/pdf/2059-0008-1-1.pdf

39. Jude AR, Little JM, Freeman JP, Evans JE, Radominska-Pandya A and Grant DF. Linoleic acid diols are novel substrates for human UDP. glucuronosyltransferases. Arch Biochem Biophys. 2000; 380:294-302. I Article | PubMed

40. Yang J, Bratt J, Franzi L, Liu JY, Zhang G, Zeki AA, Vogel CF, Williams $\mathrm{K}$, Dong $\mathrm{H}$, Lin $\mathrm{Y}$, Hwang $\mathrm{SH}$, Kenyon NJ and Hammock BD. Soluble epoxide hydrolase inhibitor attenuates inflammation and airway hyperresponsiveness in mice. Am J Respir Cell Mol Biol. 2015; 52:46-55. | Article | PubMed

41. Podolin PL, Bolognese BJ, Foley JF, Long E, 3rd, Peck B, Umbrecht S, Zhang $X$, Zhu $P$, Schwartz $B$ and Xie $W$ et al. In vitro and in vivo characterization of a novel soluble epoxide hydrolase inhibitor. Prostaglandins Other Lipid Mediat. 2013; 104-105:25-31. I Article I PubMed

42. GlaxoSmithKline. A study to assess the safety, tolerability, pharmacokinetics and pharmacodynamics of single doses of GSK2256294 in healthy volunteers, and single and repeat doses of GSK2256294 in adult male moderately obese smokers. Clinical Trial Identifier NCT01762774. 2014.

\section{Citation:}

Nording ML, Yang J, Hoang L, Zamora V, Uyeminami D, Espiritu I, Pinkerton KE, Hammock BD and Luria A. Bioactive lipid profiling reveals drug target engagement of a soluble epoxide hydrolase inhibitor in a murine model of tobacco smoke exposure. J Metabolomics. 2015; 1:1. http://dx.doi.org/10.7243/2059-0008-1-1 